\title{
TEKNIK MENARASIKAN PUISI SEBAGAI UPAYA MENINGKATKAN KREATIVITAS SISWA
}

\author{
Novi Rahmania Aquariza \\ Universitas Nahdlatul Ulama Surabaya \\ E-mail:rahmania.novi@gmail.com
}

\begin{abstract}
Abstrak
Dalam mewujudkan pengajaran sastra yang menyenangkan, terlepas dari kejenuhan guru dan siswa, maka diperlukan adanya pemilihan teknik yang tepat diikuti dengan pemilihan bahan ajar serta media ajar yang juga sesuai. Berdasarkan pernyataan tersebut, maka artikel ini bertujuan menyajikan rancangan teknik, media dan bahan ajar yang dapat digunakan demi mewujudkan pengajaran sastra yang menyenangkan dan diharapkan dapat menstimulus kreativitas siswa. Pertama, artikel ini menyajikan ragam teknik pengajaran sastra, utamanya puisi. Kedua, artikel ini juga berfokus pada suatu teknik pengajaran puisi yang dinilai dapat dijadikan sebagai upaya meningkatkan kreativitas siswa, yaitu teknik menarasikan puisi. Teknik menarasiikan puisi akan disajikan lengkap dengan media ajar yang menunjangnya.
\end{abstract}

Kata Kunci: narasi, puisi, kreativitas.

\begin{abstract}
In the effort of creating a joyful literary teaching, avoiding the boredom of both teachers and students, thus it needs the selection of a proper technique followed by the selection of a proper source too. Based on that statement, this article aimed to share the design of a proper technique and source which can be used in creating a joyful literary teaching. Hopefully it can stimulate the students creativity. In the beginning, this article serves the types of technique in literary teaching, especially for poetry. Then, this article also focused on the technique of poetry teaching which can be used as an effort to increase the students' creativity, that is narrating a poetry. The technique of narrating a poetry will be served by the supporting source.
\end{abstract}

Keywords: narrate, poetry, creativity 


\section{PENDAHULUAN}

Mempelajari sastra adalah sesuatu hal yang menyenangkan. Bahkan menurut Zulela, sastra memiliki beragam alasan untuk diajarkan. Alasanalasan tersebut antara lain adalah bahwa sastra menunjukkan kebenaran hidup. Dalam hal ini, sastra mengungkapkan pengalaman manusia agar manusia lain dapat mengambil pelajaran dari pengalaman itu dan menjalani hidup dengan lebih baik. Sastra melampaui batas bangsa dan zaman. Sebuah karya sastra mampu membuat pembacanya seakan-akan berada pada masa lalu ataupun masa depan sesuai dengan gambaran yang ada pada karya sastra tersebut. Dengan sastra, dapat memiliki santun berbahasa. Keindahan dan kesantunan bahasa yang terdapat dalam suatu karya sastra membuat pembacanya akan secara tidak langsung menerapkannya dalam keseharian. Sastra dapat menjadikan manusia berbudaya, yang berarti manusia cepat tanggap terhadap segala hal yang luhur dan indah dalam hidup ini (Zulela, 2012: 20-23).

Begitu pentingnya sastra untuk diajarkan dalam pendidikan formal, namun pada kenyataannya mengajarkan dan mempelajari sastra tidak semudah yang dibayangkan. Pengajar dituntut untuk dapat mengajarkan sastra secara menarik, menghindari kejenuhan yang mungkin timbul pada peserta didik. Demikian halnya dengan peserta didik, diperlukan rasa ketertarikan terhadap sastra. Disini keduanya saling membutuhkan.

Untuk mewujudkan suatu pembelajaran sastra yang menyenangkan, terlepas dari kejenuhan pendidik dan peserta didik maka tidak dapat dipungkiri adanya kebutuhan pemakaian teknik yang tepat oleh si pendidik, dalam hal ini guru.

Teknik pembelajaran merupakan cara guru dalam menyampaikan bahan ajar yang telah disajikan, mengacu pada pendekatan yang dianut. 176 | ISSN: 22477-5150 http://journal.unesa.ac.id/index.php/jpi 
Teknik yang digunakan guru hendaknya disesuaikan pada kemampuan guru tersebut mencari akal atau siasat agar proses belajar dan mengajar dapat berjalan dengan hasil optimal. Dalam menentukan teknik pembelajaran apa yang sebaiknya digunakan, guru perlu mempertimbangkan beberapa hal antara lain; situasi kelas, lingkungan, karakteristik siswa, serta beberapa kondisi lainnya. Dengan demikian, teknik mengajar yang digunakan oleh guru dapat sangat bervariasi.

\section{TEKNIK DALAM PENGAJARAN PUISI}

Dalam pengajaran sastra, utamanya pengajaran puisi, terdapat beberapa teknik yang dapat digunakan, antara lain: membaca puisi secara serempak, membaca puisi secara individu, melagukan puisi, memerankan puisi, menarasikan puisi, mengganti puisi, menulis puisi berdasarkan objek langsung, menulis puisi berdasarkan lamunan, menulis puisi berdasarkan cerita, meneruskan puisi, mengawali puisi, serta membaca puisi secara berpasangan (Suyatno, 2012:140-150).

1. Baca puisi serempak

Dalam teknik ini siswa membaca puisi dengan benar tentang lafal, intonasi dan gerakan sesuai tema secara serentak.

2. Baca puisi individu

Dalam teknik ini siswa diharapkan dapat mengapresiasi puisi dengan ekspresi lisannya. Siswa membaca puisi secara perseorangan dengan bebas.

3. Melagukan puisi

Dalam teknik ini siswa dapat dengan cepat membuat sebuah lagu berdasarkan puisi yang disenanginya. Siswa biasanya senang 
dengan lagu-lagu, agar lebih variatif, lagu tersebut baitnya diganti dengan bait puisi. Setelah itu siswa melagukan puisi yang disenangi dengan nada yang dipilihnya. Kemudian menyanyikannya di depan kelas.

4. Memerankan puisi

Dalam teknik ini siswa dapat memerankan isi puisi dengan benar berdasarkan imajinasi mereka. Siswa diminta untuk memerankan isi puisi tersebut sesuai dengan imajinasi. Setelah dirasa dapat memahami dan menyusun peran, siswa menampilkan di depan kelas.

5. Menarasikan puisi

Dalam teknik ini siswa dapat mengubah bermacam-macam bentuk puisi menjadi sebuah cerita dengan narasi dengan tepat.

6. Mengganti puisi

Dalam teknik ini siswa dapat membuat variasi puisi berdasarkan imajinasi yang dimiliki dengan benar. Siswa mengganti puisi dengan kata-katanya sendiri. Yang diganti tentunya tidak semua persajakannya, tetapi beberapa kata yang dipandangnya pantas diubah. siswa wajib mengubahnya meskipun puisi itu sudah dipandang baik.

7. Menulis puisi berdasarkan objek langsung

Dalam teknik ini siswa dapat menulis puisi dengan cepat dan tepat berdasarkan objek yang dilihatnya secara langsung. Siswa menulis puisi berdasarkan objek langsung yang dilihatnya. Siswa diajak keluar kelas untuk melihat objek yang mereka senangi kemudian menuliskannya ke dalam puisi.

8. Menulis puisi berdasarkan lamunan 
Dalam teknik ini siswa dapat menulis puisi dengan cepat dan benar berdasarkan lamunan atau imajinasinya. Siswa diajak untuk melamunkan sesuatu (contohnya tokoh idola, alam, hewa, atau apa saja) kemudian menuliskan ke dalam puisi.

9. Menulis puisi berdasarkan gambar

Dalam teknik ini siswa dapat menulis puisi dengan cepat dan benar berdasarkan gambar yang diberikan oleh guru. Dengan melihat gambar tersebut, siswa menulis puisi.

10. Menulis puisi berdasarkan cerita

Dalam teknik ini siswa dapat membuat puisi dengan cepat berdasarkan cerita yang dibacanya. Siswa membaca cerita dalam waktu yang telah ditentukan. Setelah itu siswa diminta menulis puisi atas dasar cerita yang telah mereka baca.

11. Meneruskan puisi

Dalam teknik ini siswa dapat meneruskan sebuah puisi dengan benar dan runtut sesuai temanya. Siswa diberi lembar puisi yang belum selesai penulisannnya. siswa meneruskan penulisan puisi yang belum selesai tersebut sehingga menjadi sebuah puisi yang utuh.

12. Mengawali puisi

Dalam teknik ini siswa dapat membuat bait pertama puisi yang belum ada awalannya dengan cepat, benar dan runtut sesuai isi. Siswa diberi lembar fotokopi puisi yang bait pertama belum ada (sengaja dihilangkan). Siswa menulis awal puisi yang sebelumnya masih kosong. diharapkan siswa dapat menyambung gagasan dengan gagasan yang sudah ditulis dalam puisi itu. 
13. Membaca puisi secara berpasangan.

Dalam teknik ini siswa dapat membaca puisi secara berpasangan dengan benar tentang lafal, intonasi, dan gerakan sesuai temanya. Siswa dibagi menjadi berpasang-pasangan. Secara berpasangan siswa membaca puisi berdasarkan interpretasi yang mereka miliki. (Suyatno, 2012:140-150)

\section{TEKNIK MENARASIKAN PUISI}

Teknik yang menjadi fokus dalam artikel ini adalah teknik menarasikan puisi. Teknik menarasikan puisi merupakan teknik dimana siswa dapat mengubah bermacam-macam bentuk puisi menjadi sebuah cerita narasi. (Suyatno, 2012:140-150)

Berikut adalah langkah-langkah pembelajaran dalam pengaplikasian teknik menarasikan puisi:

1. Kegiatan awal

2. Kegiatan inti

a. Guru memberikan penjelasan tentang kegiatan yang aka dilaksanakan

b. Guru memberikan kesempatan kepada siswa untuk mengidentifikasi puisi yang dipilihnya

c. Secara individu, siswa mengubah puisi yang telah diidentifikasikan ke dalam bentuk cerita/narasi.

d. Secara individu, siswa menampilkan hasil karyanya di depan kelas.

e. Guru memberikan kesempatan kepada siswa audien untuk menilai penampilan siswa penyaji.

f.Guru merefleksikan hasil pembelajarn pada hari itu.

3. Kegiatan penutup (Suyatno, 2012:140-150) 


\section{Teknik menarasikan puisi sebagai upaya meningkatkan kreativitas siswa}

Dalam pembahasan ini, dapat dirumuskan terlebih dahulu pengertian narasi. Narasi adalah ragam wacana yang menceritakan proses kejadian suatu peristiwa. sasarannya adalah memberikan gambaran yang sejelasjelasnya kepada pembaca mengenai fase, urutan, langkah atau rangkaian terjadinya sesuatu hal. (Saddhono, 2014:159)

Selanjutnya adalah perumusan tentang menulis. Menulis termasuk dalam kegiatan yang kompleks karena melibatkan cara berpikir teratur dan berbagai persyaratan yang berkaitan dengan teknik penulisan; antara lain adanya kesatuan gagasan, penggunaan kalimat yang jelas dan efektif, paragraf yang disusun dengan baik, penerapan kaidah ejaan yang benar dan perbendaharaan kata yang mencukupi. Selain itu, kegiatan menulis pun sangat erat kaitannya dengan penalaran yang merupakan proses berpikir sistematik dan logis untuk memperoleh sebuah kesimpulan. (Saddhono, 2014:152-153)

Terdapat banyak manfaat dari kegiatan menulis; antara lain peningkatan kecerdasan, pengembangan daya inisiatif dan kreatifitas, penumbuhan keberanian dan pendorong kemauan serta kemampuan dalam mengumpulkan informasi. (Saddhono, 2014:161) Jika seorang guru memutuskan memilih kegiatan menulis untuk siswanya, sudah pasti guru tersebut menginginkan agar siswanya mendapatkan semua manfaat dari kegiatan menulis.

Berikutnya, dapat dirumuskan bahwa menarasikan puisi adalah teknik mengembangkan puisi kedalam suatu bentuk tulisan narasi. Dari paparan sebelumnya, jelas tertera bahwa kegiatan menulis berperan 
langsung dalam meningkatkan kreativitas siswa. Begitu pula dalam teknik menarasikan puisi, guru memberikan puisi sebagai stimulus agar siswa dapat mengembangkannya kedalam bentuk narasi.

Tujuannya adalah agar siswa dapat mengembangkan puisi yang telah disediakan kedalam bentuk narasi. Maka tulisan yang dibuat siswa nantinya bukanlah sejenis karangan bebas, melainkan sebuah bentuk pengembangan tulisan dari topik yang telah disediakan. Dalam hal ini topik yang dimaksud adalah puisi yang telah diberikan oleh guru.

Pada hakikatnya, kegiatan mengarang bebas dapat mengembangkan kreativitas siswa. Karena siswa dapat memilih bahasan apa yang hendak ia tulis. Sebaliknya, menarasikan puisi atau mengembangkan puisi kedalam suatu bentuk narasi justru akan membuat pemikiran dan daya kreativitas siswa berkembang karena siswa diminta untuk menulis topik yang telah disediakan. Disini terukur sejauh mana siswa siap dengan tantangan dan hal baru yang belum pernah diprediksi sebelumya.

\section{MEDIA AJAR PENUNJANG}

Dalam pelaksanaan pembelajaran menggunakan teknik menarasikan puisi ini, diperlukan adanya penggunaan media ajar. Dalam hal ini penulis memilih penggunaan media papan buletin.

Papan buletin merupakan salah satu jenis media visual yang ada. Jenis-jenis media visual lainnya seperti halnya;
a. Gambar
b. Sketsa
C. Diagram
d. Bagan/chart
e. Grafik 

f. Kartun
g. Poster
h. Peta dan globe
i. Papan flanel
j. Papan buletin (Musfiqon, 2012:88)

Papan buletin memiliki beberapa perbedaan dengan papan flanel, papan ini tidak dilapisi kain flanel tetapi langsung ditempel gambargambar atau tulisan-tulisan. Fungsinya selain untuk menampilkan sesuatu, papan buletin dimaksudkan untuk menunjukkan kejadian yang berlangsung dalam waktu tertentu.

Berbagai jenis media grafis seperti gambar, poster, skestsa, diagram, atau bahkan bagan dapat dipakai sebagai bahan pembuatan papan buletin. Tidak hanya itu, papan buletin dapat dibuat dari pesan-pesan verbal tertulis seperti karangan anak-anak, berita, feature dan sebagainya. (Sadiman dalam Musfiqon, 2012:88-89)

Dalam kaitannya dengan pengajaran sastra meggunakan teknik menarasikan puisi, papan buletin berfungsi sebagai alat bantu penyaji narasi dari puisi hasil karya siswa. Guru memilih beberapa narasi terbaik untuk dipamerkan dalam papan buletin. Siswa akan merasa bangga karena karyanya merupakan salah satu karya terbaik pilihan guru. Melalui papan buletin ini, karya siswa yang terpilih dapat dinikmati oleh siswa lain dan memotivasi mereka untuk membuat hal serupa atau bahkan mungkin jauh lebih baik. Kompetisi sehat seperti ini juga akan memacu kreativitas siswa untuk terus berkarya menghasilkan yang terbaik.

\section{SIMPULAN}


Diperlukan suatu pengajaran sastra yang tidak hanya menyenangkan tetapi juga dapat membantu siswa meningkatkan kreativitasnya. Teknik menarasikan puisi merupakan jawaban dari kebutuhan mengajarkan sastra secara menyenangkan dan dapat meningkatkan kreativitas siswa. Didukung dengan penggunaan media ajar papan buletin, aka sangat melengkapi dan membantu dalam menyajikan karya siswa. Hal ini merupakan suatu bentuk kompetisi sehat yang dapat membantu memotivasi siwa lain berlomba-lomba mengahsilkan karya yang serupa atau bahkan jauh lebih baik.

\section{DAFTAR RUJUKAN}

Iskandarwassid. 2010. Strategi Pembelajaran Bahasa. Bandung: PT. Remaja Rosdakarya

Musfiqon. 2012. Pengembangan Media dan Sumber Pembelajaran. Jakarta: Prestasi Pustaka

Saddhono, Kundharu dan Slamet. 2014. Pembelajaran Keterampilan Berbahasa Indonesia. Yogyakarta: Graha IImu

Suyatno. 2012. Teknik Pembelajaran Bahasa dan Sastra. Surabaya: Penerbit SIC.

Zulela. 2013. Pembelajaran Bahasa Indonesia: Apresiasi Sastra di Sekolah Dasar. Bandung: PT. Remaja Rosdakarya. 